\title{
ПУТИ РАЗРАБОТКИ ГЛУБОКО ЗАЛЕГАЮЩИХ ЗАЛЕЖЕЙ ВЫСОКОВЯЗКИХ НЕФТЕЙ РУССКОГО МЕСТОРОЖДЕНИЯ
}

Гринченко А.А., Гринченко В.А., Корабельников А.И.

\section{(ООО "Тюменский нефтяной научный иентр")}

В последнее время отмечается интерес многих нефтяных компаний к месторождениям вязкой и высоковязкой нефти. Это связано с тем, что разработка высокопродуктивных объектов месторождений Западной Сибири характеризуется снижением добычи нефти и прогрессирующим ростом обводненности.

Одним из крупнейших месторождений вязкой нефти в России является Русское месторождение, расположенное на территории Ямало-Ненецкого автожомного округа в северной части Пур-Тазовского междуречья.

Нефтегазовая залежь приурочена к сеноманским отложениям (пласты ПК $1-7$ ). Продуктивные толщины залегают на глубине 660-920 м и сложены неоднородными и слабосцементированными песчано-алевролитовыми породами. Нефтяная оторочка на всей площади имеет контакт с подстилающей водой, на $70 \%$ площади - с газовой шапкой.

Несмотря на то, что нефть является тяжелой (плотность в пластовых условиях 0,902 т/см3), высоковязкой ( $\mu \mathrm{H}=217$ мПа॰с в пластовых условиях и 490 мПа॰с в поверхностных), она отличается высоким качеством: низким содержанием серы $(0,31 \%)$, парафина $(1,09 \%)$ и смол $(10,1 \%$.)

Данное месторождение было открыто более 30-ти лет назад, однако оно до сих пор не разрабатывается. Основными сдерживающими факторами ввода месторождения в громышленную разработку являются высокая вязкость нефти, наличие обштрной газовой шапки и водоносной области, слабосцементированность и неоднородность продуктивного коллектора, значительная мощность вечномерзльх пород, удаленность от транспортной системы и отсутствие инфраструктуры.

Целью данной работы являлся анализ существующих технологий извлечения высоковязкой нефти и нахождение оптимальных стратегий разработки месторождения Русское на основе результатов моделирования.

В работе рассмотрены особенности расчетов технологических показателей для всего месторождения, моделирования различных методов воздействия на пласт и внедрения, как новых наукоемких технологий, так и методов имеющих длительную историю применения у нас в стране и за рубежом. Проведен анапхз влияния различных параметров композищионной модели на точность и физичность воспроизведения описываемых процессов.

К технологиям разработки месторождений высоковязких нефтей можно отнести бурение горизонтальных, наклонно-направленных и многозабойных скважин, применение различных методов воздействия на пласт, таких как нагнетание в пласт теплоносителей (стационарная и циклическая закачка пара, SAGD, VAPEX, закачка горячей воды), водогазовое воздействие, применение химических агентов (полимеры, щелочи и т.д.).
Данные методы могут быть разделены на две основные групшы, термальные и не термальные. Моделирование термальных методов требует значительного времени расчетов, даже с использованием современных компьютерных систем. Так, например, моделирование циклической закачки пара является одной из самых сложньг задач из-за резкого изменения движения теплового фронта и потока жидкости, изменения относительньх фазовых проницаемостей и фазового состояния с изменением температуры, других факторов.

В качестве гидродинамического симулятора использовался пакет ECLIPSE 500. Была создана псевдокомпозиционная модель, учитываюшая изменения вязкости, относительных фазовых проницаемостей и остаточной насыщенности от температуры.

В ходе работы была получена оценка влияния шага по сетке (в натравлении х и у), в результате чего для моделирования был выбрана сетка с размерами $10 \times 10$ метров. Данный размер сетки обеспечивает приемлемую точность расчетов, однако, гидродинамическое моделирование термальньх методов воздействия по всей залежи с использованием такой сетки становится практически невыполнимой задачей. Поэтому для расчета технологических показателей использовались секторные модели, включающие элемент разработки, состоящий из нескольких добывающих и нагнетательных скважин, с размещенной в центре добывающей скважиной. Также рассматривались различные варианты размещения и конструкции скважин, методы воздействия, параметры закачки теплоносителей.

Как показьпает опыт, эффективность методов теплового воздействия в значительной степени зависит от выбранныг ключевых параметров, таких как объем и интенсивность закачки теплоносителя. При использовании циклической закачки пара необходимо оптимизировать длительность периодов закачки, пропитки и последующей добычи для увеличения дополнительно извлекаемой нефти. Также важно учитывать, что последовательность циклов для близлежащих скважин оказывает влияние на добычу вследствие интерференции.

По результатам расчетов, а также на основе мирового опыта разработки месторождений вязкой нефти, предлагаются наиболее оптимальные технологии нефтеизвлеqения, применимые на Русском месторождении.

\section{ЛИТЕРАТУРА:}

K. Revana, H.M. Erdogan. "Optimization of Cyclic Steam Stimulation Under Uncertainty", статья SPE 107949;

Larty J. Gipson. "Hamaca eavy Oil Project - Lessons Learned", craтья SPE 78990 